\title{
Changes in milking parameters with robotic milking
}

\author{
B. Sitkowska ${ }^{1}$, D. Piwczyński ${ }^{1}$, J. Aerts ${ }^{2}$, and M. Waśkowicz ${ }^{2}$ \\ ${ }^{1}$ UTP University of Science and Technology, Faculty of Animal Breeding and Biology, Department of Genetics \\ and General Animal Breeding, Bydgoszcz, Poland \\ ${ }^{2}$ Lely East sp. z o.o, Bydgoszcz, Poland \\ Correspondence to: B. Sitkowska (sitkowskabeata@gmail.com)
}

Received: 5 November 2014 - Accepted: 24 February 2015 - Published: 27 March 2015

\begin{abstract}
The aim of this present study is to describe changes occurring during the milking of cows in various periods following the introduction of an AMS (automatic milking system). The following cow milking parameters were analysed: milkings per cow per day, milking yield, milking speed and milking duration. An increase in milk yield in AMS barns has been found to be possible, but it is affected by a number of factors related to cow milking performance. Milk yield was observed to gradually grow with time after the installation of the robots. Older cows in their third and fourth lactations achieved higher milking parameter values as compared to cows in their first and second lactations. The average milk yield for the whole period was on a similar level, but, due to the fact that the duration of lactation in herd B was more than 100 days longer, that herd achieved a higher milk yield. The use of AMSs in barns enables farmers to monitor cow performance traits and study the relationships between them; farmers should try to select for traits ensuring high performance and directly related to milk yield. This study found a positive relationship between milking duration and milk yield. On the other hand, a highly negative relationship was found between milking duration and milking speed, which means that these parameters should be closely monitored. This study found that the optimal number of milkings per cow per day was in the range of 2.6 to 2.8 milkings a day with a $2.6 \mathrm{~kg} \mathrm{~min}^{-1}$ milking speed.
\end{abstract}

\section{Introduction}

An automatic milking system (AMS) allows each cow to be milked on an individual basis and at a place from which the animal can see its herd, which reduces milking-related stress. As emphasised by numerous authors (Hogeveen et al., 2001; Pirlo et al., 2005; Edwards et al., 2014; Lee and Choudhary, 2006), it is important that animals have a positive experience at milking time and do not mind using the AMS. The milking robots currently used allow cows to freely chose the time of milking and to dynamically adjust the intermilking interval throughout lactation as well as throughout the day (Carlström et al., 2013). Cows introduced to AMS barns quickly adapt to the new way of milking, and farmers with milking robots can precisely track many parameters related to the milking performance of their cows. Milk yield, milking frequency, intermilking interval, teat-cup attachment success rate and the length of the milking procedure are only some parameters that can be analysed with the use of robots. These parame- ters are also important criteria farmers should pay particular attention to with the aim of achieving optimum cow performance (Gygax et al., 2007; Olechnowicz et al., 2006). Farmers usually want to reduce milking duration without affecting milk yield; at the same time, they want to increase the size of the herd and obtain more milk. Such conditions may only be achieved through increased milking speed. As reported by Lee and Choudhary (2006), milking duration is negatively correlated with milking speed. At the same time, the selection of animals for a higher milking speed is risky and may lead to damaged udders and mastitis. Sivarajasingam et al. (1984) have defined milking speed as one of the most important traits affecting the profitability of milk production. In some countries, this trait has constituted one of selection criteria and has been incorporated into breeding programmes of dairy cattle. An AMS allows farmers to monitor milking speed, milking flow and milking duration, which offers opportunities to improve their levels and hence provides a 
Table 1. The level of traits related to cow milk yield in farms equipped with an AMS.

\begin{tabular}{llll}
\hline Level of traits in lactation & & \multicolumn{2}{c}{ Herd } \\
\cline { 3 - 4 } & & $\mathrm{A}$ & $\mathrm{B}$ \\
\hline & Number of cows & 61 & 58 \\
\hline Average for the year & share of primiparous cows (\%) & 54 & 53 \\
prior to AMS installation & lactation duration (days) & 395.61 & 418.4 \\
& milk yield per lactation (kg) & 8808.22 & 10831.8 \\
& fat content (\%) & 4.13 & 3.96 \\
& protein content (\%) & 3.26 & 3.43 \\
& lactose content (\%) & 4.93 & 4.82 \\
& dry-matter content (\%) & 12.99 & 12.93 \\
\hline Averages 1 year after & share of primiparous cows (\%) & 44.2 & 44.8 \\
AMS installation & lactation duration (day) & 348.52 & 460.47 \\
& milk yield per lactation (kg) & 8938.2 & 12911.5 \\
& fat content (\%) & 3.96 & 3.82 \\
& protein content (\%) & 3.30 & 3.54 \\
& lactose content (\%) & 4.90 & 4.87 \\
& dry-matter content (\%) & 12.88 & 12.91 \\
\hline
\end{tabular}

greater potential for profitable dairy production (Gray et al., 2012; Edwards et al., 2014).

The aim of the present study was to identify changes occurring during the milking of cows in various periods following the introduction of an AMS. The focus has been on the following milking parameters that are important for the farmer: milkings per cow per day (MCD), milk yield (MY), milking speed (MS) and milking duration (MD).

\section{Materials and methods}

The material for the study was collected in Poland at two Polish Holstein-Friesian (PHF) dairy cattle farms, equipped with an AMS. The system was introduced at the two farms in October 2011. Both facilities had similar housing and feeding conditions. An average of 60 cows was held on a slatted floor; the sizes of the barns were similar, about $50 \mathrm{~m} \times 24 \mathrm{~m}$. Feed was distributed at 9 a.m.; with herd A, the AMS was cleaned and maintained three times a day, whereas with herd B, these activities were performed twice a day. The following parameters were studied: MCD, MY, MS and MD. Changes in the levels of traits were analysed over 6-monthly periods after the installation of the robot. Following processing and selection, the database contained 48160 records on which statistical analysis was performed.

The statistical effects of the factors studied on recorded traits were verified by general linear models (GLMs) procedure (SAS, 2014). The following multifactor linear model was used:

$$
\begin{gathered}
Y_{i j k l m n o p}=h_{j}+l_{k}+s_{l}+t_{m}+(h l)_{j k}+\ldots+(s t)_{l m} \\
+\mathrm{DIM}_{n}+\mathrm{TD}_{o}+\sum_{u=1}^{3} r_{p u} Z_{u n}+e_{i j k l m n o p},
\end{gathered}
$$

where $y_{i j k l m n o p}$ is the ijklmnopth observation of a cow, $h_{j}$ is the fixed effect of the $j$ th farm $(1,2), l_{k}$ is the fixed effect of the $k$ th consecutive lactation $(1,2), s_{l}$ is the fixed effect of the $l$ th calving season (1-4), $t_{m}$ is the fixed effect of the $m$ th period of operation of the AMS (1-4), $\mathrm{DIM}_{n}$ is the fixed effect of days in milk (DIM) $n$ in 300 classes where day 6 is the first class and day 305 the last class, $\mathrm{TD}_{o}$ is the fixed effect of test day $o$, (hp) $j_{k \ldots}$ (st) ${ }_{l m}$ is the respective interaction between fixed effects, and $Z_{u n}$ represents the Legendre polynomials modified by Gengler et al. (1999):

$z_{0}=1 ; z_{1}=\sqrt{3 x} ; z_{2}=\sqrt{5 / 4\left(3 x^{2}-1\right)} ;$

$x=\frac{2(t-5)}{t_{\max }-t_{\min }}-1$,

where $t$ is the day of test milking $\left(t_{\max }, t_{\min }\right.$ - time of maximum and minimum day of test milking), $r_{p u}$ is the random regression coefficient on $Z_{u n}$ for the permanent environmental effect $p$ and $e_{i j k l m n o p}$ is the random residual connected with ijklmnopth observation.

The calving season was divided into four periods: winter (December, January, February), spring (March, April, May), summer (June, July, August) and autumn (September, October, November). Two groups were selected by lactation type: primiparous and multiparous cows (from second to fourth 


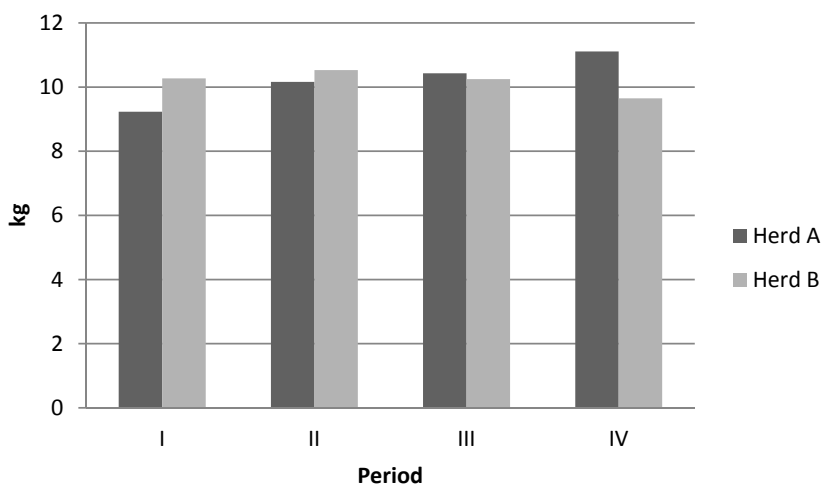

Figure 1. Levels of milk yield in herds under study.

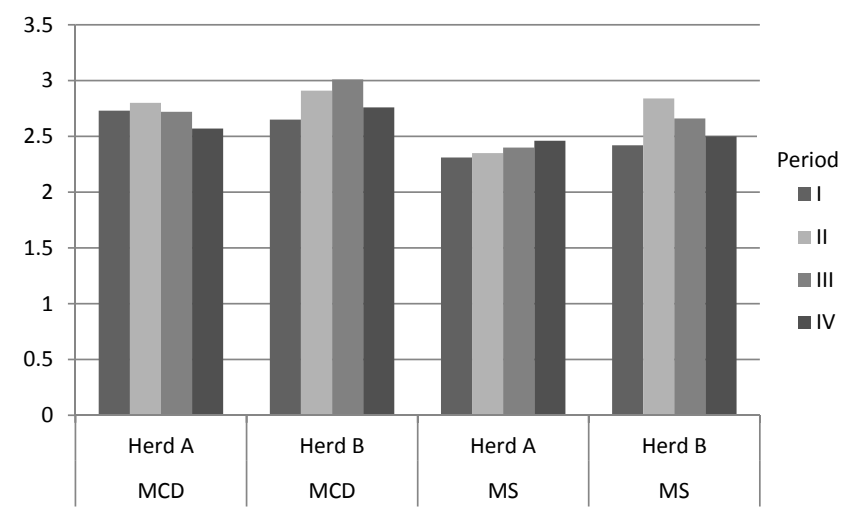

Figure 2. Levels of milkings per cow per day (MCD) and milking speed (MS, $\mathrm{kg} \mathrm{min}^{-1}$ ) in herds under study.

lactation). The 2-year operation of the AMS at the farm was divided into four 6-month periods.

\section{Results}

The general characteristics of the population under study is presented in Table 1. The share of primiparous cows in the herds under study prior to introducing the AMS had been more than $50 \%$, and following the introduction of the robot it fell to about $44 \%$. In herd B, both in the period to and during the operation of the AMS, cows in full lactation were milked for longer than in herd A. In herd B, the average lactation was longer than in herd A by more than 100 days. The average milk yield in lactation increased in both herds following the introduction of the AMS. In herd A, it rose by about $120 \mathrm{~kg}$ in lactation, and in herd $\mathrm{B}$, it rose by more than $2000 \mathrm{~kg}$, which might be directly related to the average duration of cow lactation. In the herds under study, herd A had a higher fat content in milk during lactation, both prior to and following the installation of the AMS, whereas the protein content was higher in herd B. Following AMS installation, the average protein content in milk rose slightly in both herds. The average level of lactose and dry matter in milk in

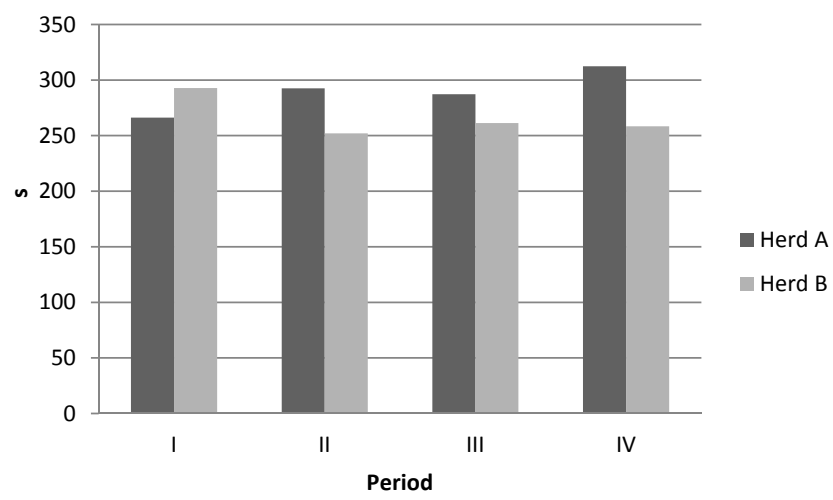

Figure 3. Level of milking duration in herds under study.

lactation prior to and following the installation of robots was similar.

Based on the statistical analysis, the effect of all factors under study and the interactions between them proved to be highly significant for the analysed traits related to the cow milking process. A detailed analysis of milking parameters depending on the level of factors studied is presented in Table 2. MY was found to be higher from the seventh month onwards of the studied period of operation of the AMS as compared to the initial period, and it stayed at a higher level until the end of the second year of data collection. Thus, from the seventh month onwards of milking with the AMS, mean MS decreased. At the same time, in the second and third period under study, the most MCD were found, accompanied by the shortest MD.

What seems to be interesting is the observation concerning the effect of the lactation stage: the highest MY was recorded in the initial phase, with a similar trend in MD and MCD. The cows calving in spring and winter were also found to have yielded the highest amount of milk, with a high MS. The lowest MY was obtained from the cows that calved in the autumn months. At the same time, over that period, the cows were milked the shortest and with a lower MS. This study found that the monitored milking parameters of older animals, following the second lactation, were characterised by a higher MY, more MCD, a higher MS and a longer MD as compared to younger cows.

Figures 1, 2 and 3 present, separately for both barns, changes in the level of traits related to the milking process of cows in the 2 years from the time of robot installation. During the first 6-month period of AMS installation, more than 7000 milkings were taken; in the second and fourth 6-month periods, the analysed number of milkings increased to more than 10000 ; and the highest number of analysed milkings occurred in the third 6-month period following installation. The lowest MY, at $9.75 \mathrm{~kg}$, was found in the initial period following the installation of the robot and the highest in the second 6-month period of installation (10.34 kg on average). Herd A 
Table 2. Level of milking parameters depending on factors studied.

\begin{tabular}{|c|c|c|c|c|c|c|}
\hline Factor & $\begin{array}{l}\text { Level of } \\
\text { factor }\end{array}$ & Statistic & $\begin{array}{l}\text { Milk } \\
\text { yield (kg) }\end{array}$ & $\begin{array}{l}\text { Milkings per } \\
\text { cow per day }\end{array}$ & $\begin{array}{l}\text { Milking } \\
\text { duration (s) }\end{array}$ & $\begin{array}{l}\text { Milking speed } \\
\left(\mathrm{kg} \mathrm{min}^{-1}\right)\end{array}$ \\
\hline \multirow[t]{4}{*}{ Lactation } & \multirow{2}{*}{$\begin{array}{l}\text { Primiparous } \\
n=29062\end{array}$} & Mean & $9.85^{\mathrm{A}}$ & $2.78^{\mathrm{A}}$ & $269.47^{\mathrm{A}}$ & $2.47^{\mathrm{A}}$ \\
\hline & & SD & 2.12 & 0.73 & 112.83 & 0.91 \\
\hline & \multirow{2}{*}{$\begin{array}{l}\text { Multiparous } \\
n=19098\end{array}$} & Mean & $10.99^{\mathrm{A}}$ & $2.81^{\mathrm{A}}$ & $286.99^{\mathrm{A}}$ & $2.61^{\mathrm{A}}$ \\
\hline & & $\mathrm{SD}$ & 2.61 & 0.81 & 137.97 & 0.89 \\
\hline \multirow[t]{8}{*}{ Calving season } & \multirow{2}{*}{$\begin{array}{l}\text { Spring } \\
n=13784\end{array}$} & Mean & $10.47^{\mathrm{ACD}}$ & $2.76^{\mathrm{AB}}$ & $278.70^{\mathrm{ABC}}$ & $2.62^{\mathrm{ABC}}$ \\
\hline & & $\mathrm{SD}$ & 2.61 & 0.76 & 133.85 & 1.04 \\
\hline & \multirow{2}{*}{$\begin{array}{l}\text { Summer } \\
n=10016\end{array}$} & Mean & $10.23^{\mathrm{CF}}$ & $2.80^{\mathrm{BDE}}$ & $284.95^{\mathrm{ADE}}$ & $2.47^{\mathrm{AD}}$ \\
\hline & & SD & 2.23 & 0.79 & 146.79 & 0.80 \\
\hline & \multirow{2}{*}{$\begin{array}{l}\text { Autumn } \\
n=12872\end{array}$} & Mean & $9.96^{\mathrm{BDEF}}$ & $2.78^{\mathrm{CD}}$ & $271.74^{\mathrm{BD}}$ & $2.47^{\mathrm{BE}}$ \\
\hline & & $\mathrm{SD}$ & 2.17 & 0.75 & 114.91 & 0.87 \\
\hline & \multirow{2}{*}{$\begin{array}{l}\text { Winter } \\
n=11488\end{array}$} & Mean & $10.53^{\mathrm{ABE}}$ & $2.83^{\mathrm{ACE}}$ & $271.48^{\mathrm{CE}}$ & $2.53^{\mathrm{CDE}}$ \\
\hline & & $\mathrm{SD}$ & 2.45 & 0.78 & 94.68 & 0.84 \\
\hline \multirow[t]{6}{*}{ Phase of lactation } & \multirow{2}{*}{$\begin{array}{l}<100 \text { th day } \\
n=14681\end{array}$} & Mean & $11.35^{\mathrm{AB}}$ & $2.93^{\mathrm{AB}}$ & $310.93^{\mathrm{AB}}$ & $2.49^{\mathrm{AB}}$ \\
\hline & & $\mathrm{SD}$ & 2.66 & 0.80 & 135.48 & 0.94 \\
\hline & \multirow{2}{*}{$\begin{array}{l}\text { Days } 100-200 \\
n=14122\end{array}$} & Mean & $10.38^{\mathrm{AC}}$ & $2.86^{\mathrm{AC}}$ & $272.52^{\mathrm{AC}}$ & $2.57^{\mathrm{AC}}$ \\
\hline & & $\mathrm{SD}$ & 2.08 & 0.77 & 115.34 & 0.92 \\
\hline & \multirow{2}{*}{$\begin{array}{l}\text { Days }>200 \\
n=19357\end{array}$} & Mean & $9.45^{\mathrm{BC}}$ & $2.63^{\mathrm{BC}}$ & $253.09^{\mathrm{BC}}$ & $2.52^{\mathrm{BC}}$ \\
\hline & & $\mathrm{SD}$ & 2.03 & 0.71 & 113.98 & 0.87 \\
\hline \multirow[t]{8}{*}{ AMS period of operation } & \multirow{2}{*}{$\begin{array}{l}\text { Month 1-6 } \\
n=7719\end{array}$} & Mean & $9.88^{\mathrm{AB}}$ & $2.68^{\mathrm{ABC}}$ & $283.03^{\mathrm{ABC}}$ & $2.37^{\mathrm{ABC}}$ \\
\hline & & & 2.72 & 0.73 & 131.47 & 0.88 \\
\hline & \multirow{2}{*}{$\begin{array}{l}\text { Month } 7-12 \\
n=12196\end{array}$} & Mean & $10.39^{\mathrm{AC}}$ & $2.86^{\mathrm{A}}$ & $266.75^{\mathrm{ADE}}$ & $2.66^{\mathrm{ADE}}$ \\
\hline & & & 2.29 & 0.76 & 117.64 & 0.99 \\
\hline & \multirow{2}{*}{$\begin{array}{l}\text { Month 13-18 } \\
n=17982 \\
\end{array}$} & Mean & $10.33^{\mathrm{BD}}$ & $2.87^{\mathrm{BD}}$ & $273.42^{\mathrm{BDF}}$ & $2.54^{\mathrm{BDF}}$ \\
\hline & & & 2.19 & 0.78 & 115.91 & 0.86 \\
\hline & \multirow{2}{*}{$\begin{array}{l}\text { Month 19-24 } \\
n=10263\end{array}$} & Mean & $10.45^{\mathrm{CD}}$ & $2.65^{\mathrm{CD}}$ & $288.19^{\mathrm{CEF}}$ & $2.47^{\mathrm{CEF}}$ \\
\hline & & & 2.55 & 0.73 & 136.14 & 0.88 \\
\hline \multirow[t]{4}{*}{ Herd } & \multirow{2}{*}{$\begin{array}{l}\text { A } \\
n=21338\end{array}$} & Mean & $10.39^{\mathrm{A}}$ & $2.69^{\mathrm{A}}$ & $292.24^{\mathrm{A}}$ & $2.39^{\mathrm{A}}$ \\
\hline & & SD & 2.20 & 0.69 & 124.24 & 0.82 \\
\hline & \multirow{2}{*}{$\begin{array}{l}\mathrm{B} \\
n=26822\end{array}$} & Mean & $10.23^{\mathrm{A}}$ & $2.87^{\mathrm{A}}$ & $263.83^{\mathrm{A}}$ & $2.64^{\mathrm{A}}$ \\
\hline & & SD & 2.53 & 0.81 & 114.97 & 0.95 \\
\hline
\end{tabular}

AA - values marked with the same capital letter are significantly different at $P \leq 0.01 ; n$ - no. of recorded milkings; SD - standard deviation.

Table 3. Pearson correlation coefficients together with their significance between the cow milking parameters studied.

\begin{tabular}{llll}
\hline Trait & Milk yield & $\begin{array}{l}\text { Milkings per } \\
\text { cow per day }\end{array}$ & $\begin{array}{l}\text { Milking } \\
\text { duration }\end{array}$ \\
\hline Milkings per cow per day & $-0.2779^{* *}$ & & \\
Milking duration & $0.3909^{* *}$ & $-0.1293^{* *}$ & \\
Milking speed & $0.1345^{* *}$ & $-0.0092^{*}$ & $-0.7092^{* *}$ \\
\hline
\end{tabular}

** $P \leq 0.01,{ }^{*} P \leq 0.05$ in the subsequent periods systematically improved its mean milk yield, the increase being more than $1 \mathrm{~kg}$ (Fig. 1).

The highest average MCD level, at 2.85 per cow, was reported in the third 6-month period following the installation of the robot. The least MCD were observed in the first period under study following installation, at about 2.69 times a day, whereas in the fourth period it was 2.78 on average in both herds studied. Despite the fact that the number of animals was similar in both herds under study, significant differences were observed in the number of milkings since the second analysed period following the introduction of milking robots. The highest number of milkings was recorded in 
herd B; also in that herd, a higher MS was found in each period studied (Fig. 2). For MD, starting from the second period under study, this trait showed higher values in herd A (Fig. 3).

Based on the estimated correlation coefficients, a low positive correlation between MD and MY was identified. Negative relationships were obtained between the following traits: MY and MCD; MCD and MD; and MD and MS. The correlation coefficient between MD and MS was high (Table 3).

\section{Discussion}

Over the period of this study, the mean yield of cows under study in Poland increased from $6980 \mathrm{~kg}$ in 2010 to more than $7441 \mathrm{~kg}$ in 2013. The mean content of fat and proteins in Poland in 2010 was at 4.18 and $3.35 \%$, respectively, whereas in 2013 the figure was 4.16 and $3.36 \%$, respectively (PFHBiPM, 2014). Therefore, the herds in which the AMS was installed were characterised by a high milk yield. At the same time, the percentage content of protein in these herds was found to be at levels similar to the national average, and the content of fat was found to be lower. Already prior studies on AMSs (Sitkowska et al., 2013) demonstrated a statistically significant effect of factors on the milk yield of cows milked by an AMS, which has been confirmed in this study.

Castro et al. (2012) found that in Spanish herds, the average number of cows per robot was about 52.7, which was significantly less than in the Polish herds studied. Castro et al. (2012), Edwards et al. (2014) and Løvendahl and Chagunda (2011) found that the mean MY from cows during milking by an AMS was about $10.70 \mathrm{~kg}$, which is similar to the figure found in this present study. A higher mean MY was obtained by Hogeveen et al. (2001), at $11.8 \mathrm{~kg}$, and in Korean studies (Lee and Choudhary, 2006), where it was more than $14.10 \mathrm{~kg}$. According to studies conducted by Bach and Busto (2005), irregular milking and voluntary cow traffic in the AMS adversely affect the milk yield, especially in multiparous cows.

Speroni et al. (2006) found that MCD values were higher during autumn-winter (cold seasons) than during springsummer (hot seasons) (2.7 vs. 2.6) and higher in primiparous (2.8) than in multiparous cows (2.5). The present study found more MCD in summer and winter months and in the group of older cows (multiparous). In investigating mean MCD, Carlström et al. (2013) and Castro et al. (2012) obtained results similar to those of the present study, whereas Gygax et al. (2007) obtained a slightly lower result, at 2.5 (range: 0.8 to 3.9 per cow). A higher MCD value in relation to the one obtained in this study was reported by Deming et al. (2013; $2.8 \pm 0.4$ times a day), and Madsen et al. (2010) reported on average as many as three milkings per day. Lower mean MCD values, i.e. from 2.1 to 2.5 , were observed by WagnerStorch and Palmer (2013), Hogeveen et al. (2001), Mačuhová et al. (2003), Carlström et al. (2013) and Bach et al. (2009).
In Munksgaard et al. (2011), all cows were milked between 2 and 4.2 times per day. Castro et al. (2012) conclude that two variables, i.e. the number of cows per robot and MS have the greatest impact on MY in barns equipped with milking robots. The authors consider that an optimal MCD value is in the range of 2.4 to 2.6 milkings a day where there are more than 60 cows per robot. This study obtained similar or higher values. As demonstrated Kuczaj et al. (2010), an increase in the daily frequency of milking cows causes an increase in the yield of milk in lactation; this was more visible in primiparous than in multiparous cows That increase was sometimes unprofitable economically.

In assessing AMS advantages and disadvantages, Svennersten-Sjaunja and Pettersson (2008) concluded that working out an adequate, regular cow traffic to the milking robots is necessary for achieving the optimum MCD and higher MY and thus for driving up profitability. The impact of MCD on MY depends on the cow milk yield level (Hogeveen et al., 2001; Olechnowicz et al., 2006). High variability in the frequency of cow visits to the robot are observed depending on the lactation stage, some changes may be also attributed to the preferences of individual animals. As emphasised by various authors (Friggens and Rasmussen, 2001; Wagner-Storch and Palmer, 2003; Carlström et al., 2013), MCD can be increased, which should drive up MY. At the same time, cows with more MCD were observed to yield about $20 \%$ more milk as compared to cows with the least MCD (Løvendahl and Chagunda, 2011). Pettersson et al. (2011) and Sorensen et al. (2008) observed, on the other hand, that, with increasing MCD, MY also grew. However, the present study could not find such straightforward relationship in some of the groups analysed. Also, Erdman and Varner (1995) found that increased MCD drive up cow milk yield, regardless of the production level of animals. As demonstrated by Deming et al. (2013), increased MCD, which drive up milk yield, may be related to a lower number of animals per robot - this makes it easier for cows to access feed and water. André et al. (2010) emphasised that a higher MCD value and herd size may increase revenues from an AMS, but this strategy is related primarily to the milk yield of individual animals. As emphasised by Nixon et al. (2009), following the introduction of an AMS, the intermilking intervals may vary widely, from very short to very long, depending on the animal. A study by Klaas et al. (2003) concluded that high-yielding cows receive a large proportion of concentrates during milking in the AMS, which induced them to go to the milking machine more frequently.

Edwards et al. (2014), based on least squares means of milking characteristics at each stage of lactation (periods of $60 \mathrm{~d}$ ) in 1500 animals in 4 herds found that the highest MY, at $12.07 \mathrm{~kg}$, was until the 60th day of lactation; after this, it then fell. Likewise, MD was the longest in the first stage of lactation, at $416 \mathrm{~s}$, and the shortest, at $316 \mathrm{~s}$, in the last (days 241-300 of lactation) stage of lactation, and a similar trend was observed in the present study. During the ini- 
tial 100 days of lactation, MD was more than $310 \mathrm{~s}$, whereas following day 200, it was $50 \mathrm{~s}$ less. A longer MD was observed also in lactations 3 and 4 as compared to lactations 1 and 2. In their studies of 31 herds with an AMS in Galicia, Castro et al. (2012) demonstrated a longer MD (7.41 min) than in the present study. Cow MD depends on many factors, such as physiological status, animal lactation stage, MY, vacuum pressure and housing; therefore, as reported by Lee and Choudhary (2006), various components that may influence this trait can be refined.

Sivarajasingam et al. (1984) suggest that MS is the next important parameter, following milk yield and milk composition, that may influence profitability in milk production. Lee and Choudhary (2006) reported a similar MS, at $2.3 \mathrm{~kg} \mathrm{~min}^{-1}$, to the one reported in the present study, especially in herd A.

Edwards et al. (2014), based on summary statistics, showed that MY, MD and MS increased with age, which is also supported by the results of the present study. At the same time, a strong negative correlation between MS and MD is observed, which is supported by the results obtained by Lee and Choudhary (2006).

In summing up the results of the present study, it has been found that the average milk yield in lactation increased in both herds following the introduction of an AMS. It was observed that an increase in milk yield in AMS barns is possible, but it is affected by a number of factors related to cow milking performance. Milking yield has been observed to have gradually grown with time since the installation of robots. Other milking performance indicators have changed as well. During the initial 100 days of lactation, cows were milked the longest and yielded the highest amount of milk; also, the MCD value was the highest in that period. Multiparous cows were observed to have achieved higher milking parameters. The mean MY level in both herds was found to have changed across various periods. The average MY for the whole period was on a similar level, but, due to the fact that the duration of lactation in Herd B was more than 100 days longer, that herd achieved a higher MY. This study found that an optimal MCD value was in the range of 2.6 to 2.8 milkings per day, with a $2.6 \mathrm{~kg} \mathrm{~min}^{-1}$ milking speed.

The use of an AMS in barns enables farmers to monitor cow performance traits and to study the relationships between them; farmers should try to select for traits that ensure high performance and are positively related to milking yield. This study found a positive relationship between MD and MY. A highly negative relationship was obtained between MD and MS, which means that these parameters should be closely monitored.

Edited by: A.-E. Freifrau von Tiele-Winckler Reviewed by: two anonymous referees

\section{References}

André, G., Berentsen, P. B. M., Engel, B., de Koning, C. J. A. M., and Oude Lansink, A. G. J. M.: Increasing the revenues from automatic milking by using individual variation in milking characteristics, J. Dairy Sci., 93, 942-953, 2010.

Bach, A. and Busto, I.: Effects on milk yield of milking interval regularity and teat cup attachment failures with robotic milking systems, Dairy Res., 72, 101-106, 2005.

Bach, A., Devant, M., Igleasias, C., and Ferrer, A.: Forced traffic in automatic milking systems effectively reduces the need to get cows, but alters eating behavior and does not improve milk yield of dairy cattle, J. Dairy Sci., 92, 1272-1280, 2009.

Carlström, C., Pettersson, G., Johansson, K., Strandberg, E., Stålhammar, H., and Philipsson, J.: Feasibility of using automatic milking system data from commercial herds for genetic analysis of milkability, J. Dairy Sci., 96, 5324-5332, 2013.

Castro, A., Pereira, J. M., Amiama, C., and Bueno, J.: Estimating efficiency in automatic milking systems, J. Dairy Sci., 95, 929936, 2012.

Deming, J. A., Bergeron, R., Leslie, K. E., and DeVries, T. J.: Associations of housing, management, milking activity, and standing and lying behavior of dairy cows milked in automatic systems, J. Dairy Sci., 96, 344-351, 2013.

Edwards, J. P., Jago, J. G., and Lopez-Villalobos, N.: Analysis of milking characteristics in New Zealand dairy cows, J. Dairy Sci., 97, 259-269, 2014.

Erdman, R. A. and Varner M.: Fixed yield responses to increased milking frequency, J. Dairy Sci., 78, 1199-1203, 1995.

Friggens, N. C. and Rasmussen, M. D.: Milk quality assessment in automatic milking system: accounting for the effects of variable intervals between milking on milk composition, Livestock Prod. Sci., 73, 45-54, 2001.

Gengler, N., Tijani, A., Wiggins, G. R., and Misztal, L.: Estimation of (Co)variance Function Coefficients for Test Day Yield with a Expectation-Maximization Restricted Maximum Likelihood Algorithm, J. Dairy Sci., 82, 1849-1872, 1999.

Gray, K. A., Cassady, J. P., Huang, Y., and Maltecca, C.: Effectiveness of genomic prediction on milk flow traits in dairy cattle, Genetics Selection Evolution, 44, 24, 2012.

Gygax, L., Neuffer, I., Kaufmann, C., Hauser, R., and Wechsler, B.: Comparison of functional aspects in two automatic milking systems and auto-tandem milking parlors, J. Dairy Sci., 90, 42654274, 2007.

Hogeveen, H., Ouweltjes, W., de Koning, C. J. A. M., and Stelwagen, K.: Milking interval, milk production and milk flow-rate in an automatic milking system, Livest Prod. Sci., 72, 157-167, 2001.

Klaas, I. C., Rousing, T., Fossing, C., Hindhede, J., and Sørensen, T. $\mathrm{J} .:$ Is lameness a welfare problem in dairy farms with automatic milking systems?, Anim. Welf, 12, 599-603, 2003.

Kuczaj, M., Preś, J., Bodarski, R., Kupczyński, R., Stefaniak, T., and Jawor, P.: Performance of milk production and cows' health status as a function of milking frequency, Med. Wet., 66, 32-36, 2010 (in Polish).

Lee, D. H. and Choudhary, V.: Study on Milkability Traits in Holstein Cows, Asian-Aust. J. Anim. Sci., 19, 309-314, 2006. 
Løvendahl, P. and Chagunda, M. G.: Covariance among milking frequency, milk yield, and milk composition from automatically milked cows, J. Dairy Sci., 94, 5381-5392, 2011.

Mačuhová, J., Tančin, V., and Bruckmaier, R. M.: Oxytocin release, milk ejection and milk removal in a multi-box automatic milking system, Livest. Prod. Sci., 81, 139-147, 2003.

Madsen, J., Weisbjerg, M. R., and Hvelplund, T.: Concentrate composition for Automatic Milking Systems - Effect on milking frequency, Livestock Sci., 127, 45-50, 2010.

Munksgaard, L., Rushen, J., de Passillé, A. M., and Krohn, C. C.: Forced versus free traffic in an automated milking system, Livest. Sci., 138, 244-250, 2011.

Nixon, M., Bohmanova, J., Jamrozik, J., Schaeffer, L. R., Hand, K., and Miglior, F.: Genetic parameters of milking frequency and milk production traits in Canadian Holsteins milked by an automated milking system, J. Dairy Sci., 92, 3422-3430, 2009.

Olechnowicz, J., Lipiński, M., and Jaśkowski, J. M.: Main issues in robotic milking of cows, Med. Wet., 62, 611-616, 2006 (in Polish).

Pettersson, G., Svennersten-Sjaunja, K., and Knight, C. H.: Relationships between milking frequency, lactation persistency and milk yield in Swedish Red heifers and cows milked in a voluntary attendance automatic milking system, J. Dairy Res., 78, 379-384, 2011

PFHBiPM: The results of breeding value of dairy cattle, available at: http://www.pfhb.pl/images/pdf/wyniki_owub/tabele_2013. pdf (retrieved: January 2015), 2014 (in Polish).
Pirlo, G., Abeni, F., Capelletti, M., Migliorati, L., and Speroni, M.: Automation in dairy cattle milking: experimental results and considerations, Ital. J. Anim. Sci., 4, 17-25, 2005.

SAS Institute Inc.: SAS/STAT ${ }^{\circledR} 94$ User's Guide Cary, NC: SAS Institute Inc., 2014.

Sitkowska, B., Aerts, J., Piwczyński, D., Pejka, B., and Mroczkowski, S.: The impact of selected factors on milk yield of cows milked in an automatic milking system, Rocz Nauk Zoot, 41, 41-49, 2014 (in Polish).

Sivarajasingam, S., Burnside, E. B., Wilton, J. W., Pfeiffer, W. C., and Grieve, D. G.: Ranking Dairy Sires by a Linear Programming Dairy Farm Model, J. Dairy Sci., 67, 3015-3024, 1984.

Sorensen, A., Muir, D. D., and Knight, C. H.: Extended lactation in dairy cows: effects of milking frequency, calving season and nutrition on lactation persistency and milk quality, J. Dairy Res., 75, 90-97, 2008.

Speroni, M., Pirlo, G., and Lolli, S.: Effect of automatic milking systems on milk yield in a hot environment, J. Dairy Sci., 89, 4687-4693, 2006.

Svennersten-Sjaunja, K. M. and Pettersson, G.: Pros and cons of automatic milking in Europe, J. Anim. Sci., 86, 37-46, 2008.

Wagner-Storch, A. M. and Palmer, R. W.: Feeding behavior, milking behavior, and milk yields of cows milked in a parlor versus an automatic milking system, J. Dairy Sci., 86, 1494-1502, 2003. 